\title{
An Integrated Water Resources and Economic Approach for Optimizing Water Allocation Policies
}

\author{
Ayman G. Awadallah, Nabil A. Awadallah \\ Faculty of Engineering, Fayoum University, Al Fayoum, Egypt \\ Email: aawadallah@darcairo.com
}

Received 29 August 2014; revised 25 September 2014; accepted 18 October 2014

Copyright (C) 2014 by authors and Scientific Research Publishing Inc.

This work is licensed under the Creative Commons Attribution International License (CC BY).

http://creativecommons.org/licenses/by/4.0/

(c) (i) Open Access

\section{Abstract}

Reservoir/river systems analysis models are generally used in the formulation and evaluation of alternative plans for responding to water related problems and needs. One of the main problems is the water resources allocation and the cost associated with pumping, if needed. Taking the appropriate decision is considered as a techno-economic issue. The case study presented in this paper involves a complex system of three dams, two pumping stations and two diversion structures all serving an agricultural production unit. The objective of this research is to determine a suitable and feasible water allocation/pumping policy as a "trade-off" between minimizing the water deficiency and the cost of pumping. To achieve this objective, a water resources model was developed using HEC-5. A multi-criteria decision approach was implemented to determine the most appropriate water release policy and the capacity of the water diversion facilities. The parameters used were subject to a sensitivity analysis to assess their relative impact on the determined policy. The suggested release policy allows a reduction of half the total of the pumping costs with only $3 \%$ reduction in the water allocation reliability, as measured by the failure frequency of demand satisfaction and the average shortage index.

\section{Keywords}

Water Resources Optimization, Water Allocation Policy, Reservoir Simulation, Techno-Economic Analysis, Multi-Criteria, Algeria

\section{Introduction}

Reservoir system management practices and associated modeling and analysis methods involve allocating sto-

How to cite this paper: Awadallah, A.G. and Awadallah, N.A. (2014) An Integrated Water Resources and Economic Approach for Optimizing Water Allocation Policies. Journal of Water Resource and Protection, 6, 1444-1456. 
rage capacity and streamflow among multiple uses and users. It also involves minimizing the risks and consequences of water shortages and flooding, optimizing the beneficial use of water, energy, and land resources, and managing environmental resources. The objective of this study is to determine the operation/release policy of a system of three reservoirs in parallel serving a specific demand. An operation policy is a set of decision rules for determining the quantities of water to be stored and released or withdrawn from a reservoir or system of reservoirs under various operating conditions. It involves diverting water from a Wadi to a pressurized irrigation system through a gravity pipe, allowing a decrease in the pumping costs with no substantial impact on water availability. This paper consists of eight (8) sections. Following the current Section 1 that serves as the introduction, next Section 2 is devoted to a quick literature review and a presentation of the study methodology. Section 3 describes the study zone with its climate, water resources and water needs. Section 4 introduces the main assumptions underlying water resources modeling and system conceptualization of the studied alternatives. Section 5 deals with the technical and economic evaluation criteria of alternatives. The results and evaluation of alternatives are depicted in Section 6 followed by a techno-economic analysis of alternatives in Section 7 leading to the final conclusions in Section 8.

\section{Literature Review and Methodology}

\subsection{Literature Review}

A great deal of work on developing and applying reservoir/river system operation models has been documented in the published literature during the past several decades. Yeh [1] provides a comprehensive state-of-the-art review of reservoir operation models with a strong emphasis on optimization methods. The USACE Hydrologic Engineering Center [2] presents a comprehensive review of reservoir system modeling and analysis approaches. Recently, Rani and Moreira [3] presented a survey of simulation and optimization modeling approaches used in reservoir systems operation problems. Optimization methods have been proved of much importance when used with simulation modeling and the two approaches when combined give the best results. This paper is in the line of this last recommendation.

Reservoir/river system analysis models were traditionally categorized as 1) simulation, 2) optimization, and 3) combinations of simulation and optimization models [4]. Optimization models automatically search for an "optimum" set of decision variable values. Simulation models are limited to predicting system performance for a user-specified set of input variable values. Alternative runs of a simulation model are made to analyze the performance of the system under variable conditions, such as for alternative operating policies [5] and can be used to determine local optimum solutions.

Development and application of decision-support tools for water resources decision-makers have focused on simulation models. The academic community and research literature have emphasized optimization techniques, particularly linear and dynamic programming, along with other nonlinear programming methods [6] and [7].

General and modular optimization tools are currently used in daily operations of multi-purpose reservoir systems. Examples of modular tools are the Hydrosoft [8] and VISTA [9]. These modular tools optimize hydropower using successive linear programming, but do not optimize non-hydropower objectives. General river basin modeling tools, such as IRIS [10] TAMUWRAP [11], MODSIM [12], AGUATOOL [13], WEAP [14] and HEC-5 [15] allow predefined policy constraints, such as the preferred sources of water supply or the relative importance of rule curves to be prioritized. However, it is rather complex to formulate these constraints as straightforward objectives. Due to the complexity of representing a multi-objective reservoir system, most models developed for a particular river basin have been "hard-wired" to represent other operating policies and physical and economic characteristics. These models have become costly and difficult to maintain, as they cannot be easily modified to changing objectives and requirements nor are they applicable to other river basins [16]. Fayaed et al. [17] presented an overview of simulation and optimization modeling methods utilized in resolving critical issues with regard to reservoir systems and stated that reservoir simulation constitutes one of the most important steps to be considered. This research is in the line of the use of reservoir simulation coupled with a multi-criteria analysis to identify quasi-optimal solution suitable for practical purposes.

\subsection{Study Methodology and Model Description}

This study opted for using a simulation model to best represent the actual situation and to run it several times 
searching for the most suitable release policy. These iterations were structured in a manner to screen the feasible solutions and then refining them to select the most appropriate alternatives. For this purpose, HEC- 5 was used, as it is a general river basin modeling tool, flexible enough to handle a wide variety of policy constraints. The HEC-5 Simulation of Flood Control and Conservation Systems computer program is applicable to a wide range of both flood control and conservation operation problems.

HEC-5 simulates the sequential period-by-period operation of a multi-purpose reservoir system for sequences of unregulated streamflows and reservoir evaporation rates. The program uses a variable time interval. Time series data include, among others, streamflow, evaporation and diversion requirements. The user also specifies the operating rules in HEC- 5 by providing the model with reservoir storage zones, diversion and minimum low-flow targets, and allowable flood flows. The model makes release decisions to empty flood control pools and to meet user-specified diversion and in stream flow targets based on computed reservoir storage levels and streamflows at downstream locations. Seasonal rule curves and buffer zones can be included in the operating rules. Multiple-reservoir release decisions are based on balancing the percent storage depletion in specified zones. Several alternatives for hydrologic flood routing methods are also available. HEC-5 has various optional analysis capabilities including computation of expected annual flood damages and single-reservoir firm yields for water supply and hydroelectric power.

The basic rationale for carrying out sequential simulation of reservoir operation is mainly the technique with which the software determines the water releases when several reservoirs are intended to provide a certain demand. Using HEC-5, the following steps are followed to determine such releases:

1) Specify all the dams that shall contribute in the provision of this demand. These dams are said to be in parallel with respect to this demand.

2) Determine the priorities with which these dams shall contribute in the provision of the required demand. This shall be based on their Equivalent Storage Level (E.S.L.). The E.S.L. is a number that varies from 1 to 5 and determines the volume stored in the dam. Namely, $1=$ level of dead storage, $2=$ top of buffer pool and also bottom of normal storage, 3 = high level of normal conservation, $4=$ level of flood control, and finally $5=$ maximal level. Five zones are enough to determine the water releases from the three simulated reservoirs.

3) Calculate releases in order to attain equal ESL's for all dams in parallel.

4) The releases are predisposed to keep the E.S.L.'s between levels 2 and 3.

\section{Study Zone Description}

\subsection{General Description}

The Study Zone is the plain of El-Khémis, which is confined between two mountainous chains in Algeria. ElKhémis is located in the Upper-Chéliff (Algeria), which constitutes with Middle-Chéliff, Lower-Chéliff and Mina the valley of Chéliff, which is the longest Wadi in Northwest Africa. The Chéliff Valley approximate area is 61,500 ha, which is equivalent to half of the Algerian irrigated lands. El-Khémis irrigated plain (more than 20,000 ha) is formed of two banks; the 10,850 ha right bank and the 9267 ha left bank. Both banks are provided with irrigation pressure networks. The two networks are not linked. Figure 1 presents a map of the Study Zone.

The hydrographic network of the Study Zone is extremely dense. The most significant Wadis are the main Chéliff Wadi and its tributaries the Deurdeur and the Harreza Wadis. Several dams were built in the Chéliff basin. Three (3) of which are located in the Upper-Chéliff zone. The releases of Harreza are currently downstream the Study Zone, due to absence of pumping station in Harreza. The characteristics of the 3 dams are summarized in Table 1.

The capacity of Ghrib Dam is twice that of Deurdeur Dam of and its watershed area is 90 times larger. Therefore, irrigation depends primarily on releases from Ghrib. Water is not diverted directly from the dams, but it is stored and then released into the wadis. From there they are pumped via three (3) principal pumping stations: Djendel and El-Khémis I (serving the right bank) and El-Khémis II (serving the left bank). This situation in turn imposes large costs of electric power for the irrigation purposes.

The objective of this study, as previously mentioned, is to determine the most appropriate release policy to allow diverting the necessary volume of water from the Deurdeur Wadi through a gravity pipe-instead of pumping-directly towards the left bank irrigation network, with a minimum impact on the water allocation reliability. The reliability could be endangered, as the Deurdeur dam is much smaller than Ghrib dam, and could be emptied if the releases are not properly determined. This water diversion will permit the following: 


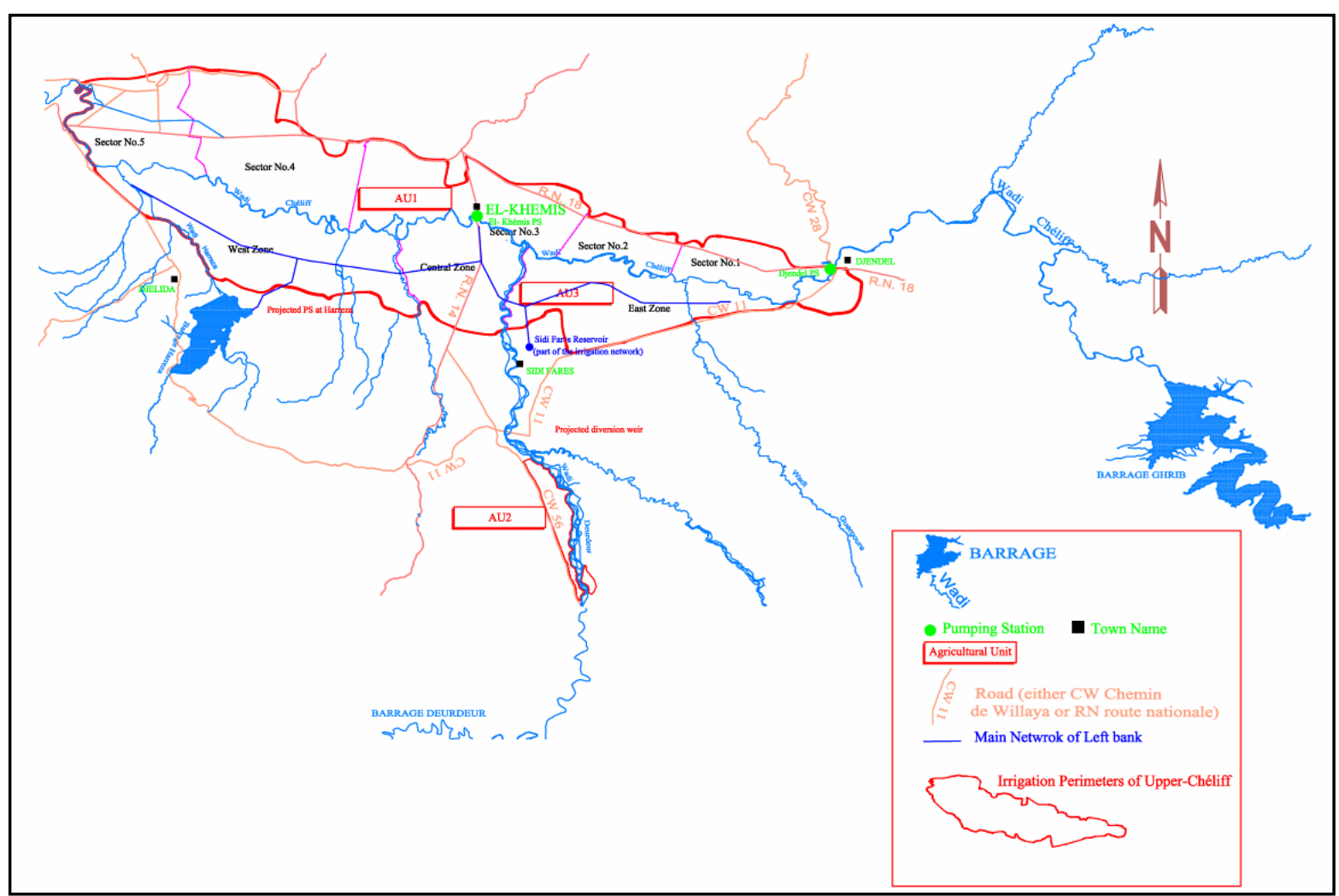

Figure 1. Map of the Upper-Chéliff Basin.

Table 1. Characteristics of the existing Dams in the Upper-Chéliff Zone.

\begin{tabular}{ccccccc}
\hline Dam Name & Wadi Name & $\begin{array}{c}\text { Catchment } \\
\text { Area }\left(\mathbf{k m}^{2}\right)\end{array}$ & $\begin{array}{c}\text { Capacity } \\
\left.\mathbf{( h m}^{3}\right)\end{array}$ & $\begin{array}{c}\text { Water Level } \\
\text { (m NGA) }\end{array}$ & $\begin{array}{c}\text { Year of } \\
\text { Service }\end{array}$ & Purpose \\
\hline Ghrib & Chéliff & 43,750 & 250 & $405-430$ & 1935 & Irrigation + Hydro-Electricity + Urban Demands \\
Harreza & Harreza & 142 & 70 & $280-295$ & 1984 & Irrigation \\
Deurdeur & Deurdeur & 468 & 110 & $580-605$ & 1985 & Irrigation + Urban \\
\hline
\end{tabular}

- A relief of the load on El-Khémis II pumping station serving the irrigation of the Upper-Chéliff left bank;

- A possible filling of the Harreza dam in exceptionally high flood periods by the surplus of the Deurdeur Wadi, without the use of pumping.

It should be noted that, considering the level of Harreza dam-which is lower than that of Deurdeur-Harreza dam shall be filled only by surplus water, which cannot be retained in Ghrib or Deurdeur. It is of no benefit to store water in a low level since the irrigation system is under pressure. Harreza filling will only occur at the exceptionally high flood years with the Deurdeur and Ghrib dams filled to the top of their respective conservation levels.

\subsection{Climate}

The climate of Upper-Chéliff is of the Mediterranean type, relatively homogeneous with hot dry summers and fresh rainy winters. The minimum yearly precipitation is close to $350 \mathrm{~mm}$, based on data series extending over the period of 1910-1983 (National Water Resources Master Plan; [18]). The seasonal distribution of precipitations is as follows:

- Winter rains (October-January) represent half the annual average precipitations;

- Summer rains (June-Sep) represent only 10\%;

- The remainder (40\%) corresponds to the period from February to May. 
The annual average temperature is approximately $16^{\circ} \mathrm{C}$. Potential evapotranspiration is homogeneous with an annual average of approximately $1550 \mathrm{~mm}$ per year. The monthly average is approximately $160 \mathrm{~mm}$ [19].

\subsection{Water Resources}

The Chéliff Wadi is characterized by extreme irregularity. The streamflow record were provided by the Algerian National Water Resources (Agence National des Ressources Hydriques, ANRH) for the wadis equipped with gauging stations and the average monthly volume runoff are summarized in Table 2.

When no gauge stations are available, regression equations were used to estimate natural volume runoffs, as it is the case for the volume runoffs of complementary catchment areas between Ghrib and Djendel and those between Djendel and Arib Chéliff [19].

\subsection{Water Demands}

Water demands for urban and industrial purposes are shown in Table 3 and those for irrigation purposes are shown in Figure 2. Agricultural Unit (AU) hereafter denotes each irrigation zone. The calculated average water requirement is $8010 \mathrm{~m}^{3} / \mathrm{ha} / \mathrm{yr}$ for the right bank of Chéliff (AU1), $8265 \mathrm{~m}^{3} / \mathrm{ha} / \mathrm{yr}$ for the left bank of Chéliff (AU3), and $5215 \mathrm{~m}^{3} / \mathrm{ha} / \mathrm{yr}$ for the lands irrigated solely by Deurdeur dam (AU2).

\subsection{Existing Dams}

The rating curves of Ghrib, Deurdeur and Harreza dams were established on the basis of the data provided by the National Dams Agency (Algeria). The levels of operation suggested in the model for the three simulated dams are shown in the Table 4.

\section{System Conceptualization and Water Resources Modeling}

Two cases were modeled:

- Case A that refers to the current situation; and

- Alternatives B that represents the integration of the water diversion from Deurdeur Wadi via the gravity pipe (alternatives B).

Table 2. Monthly and annual average volume runoffs (1947-1995).

\begin{tabular}{|c|c|c|c|c|c|c|c|c|c|c|c|c|c|}
\hline \multicolumn{14}{|c|}{ Volume Runoff $\left(10^{6} \mathrm{~m}^{3}\right)$} \\
\hline & Sep & Oct & Nov & Dec & Jan & Feb & Mar & Apr & May & Jun & Jul & Aug & Annual \\
\hline Ghrib & 6.53 & 15.81 & 6.20 & 11.46 & 25.22 & 22.46 & 20.03 & 14.51 & 8.62 & 3.86 & 1.78 & 1.55 & 138.03 \\
\hline Harbil & 0.09 & 0.73 & 1.11 & 2.29 & 3.35 & 3.57 & 3.78 & 1.93 & 1.01 & 0.36 & 0.14 & 0.01 & 18.40 \\
\hline Deurdeur & 0.66 & 2.10 & 1.30 & 4.02 & 6.37 & 7.84 & 8.09 & 4.65 & 2.26 & 0.72 & 0.41 & 0.16 & 38.58 \\
\hline Harreza & 0.21 & 0.36 & 0.45 & 0.49 & 0.54 & 1.19 & 0.98 & 0.83 & 0.39 & 0.10 & 0.04 & 0.03 & 5.61 \\
\hline
\end{tabular}

Table 3. Urban and industrial annual water demands for the towns served by the releases of the Dams in the Upper-Chéliff Zone $\left(10^{6} \mathrm{~m}^{3}\right)$.

\begin{tabular}{ccccc}
\hline \multirow{2}{*}{ Town name } & \multicolumn{2}{c}{ Water demand $\left(\mathbf{1 0}^{\mathbf{6}} \mathbf{~ m}^{3}\right)$} & \multirow{2}{*}{$\begin{array}{c}\text { Dam satisfying } \\
\text { this demand }\end{array}$} \\
\cline { 2 - 4 } & Urban & Industrial & Total & Ghrib \\
Média & 19 & 5 & 24 & \\
Djendel & 5 & 0 & 5 & Deurdeur \\
Zoubiria & 2 & 0 & 2 & \\
Théniet El-Had & 7 & 0 & 7 & \\
Bordj Amir Khaled & 2 & 0 & 2 & \\
\hline
\end{tabular}




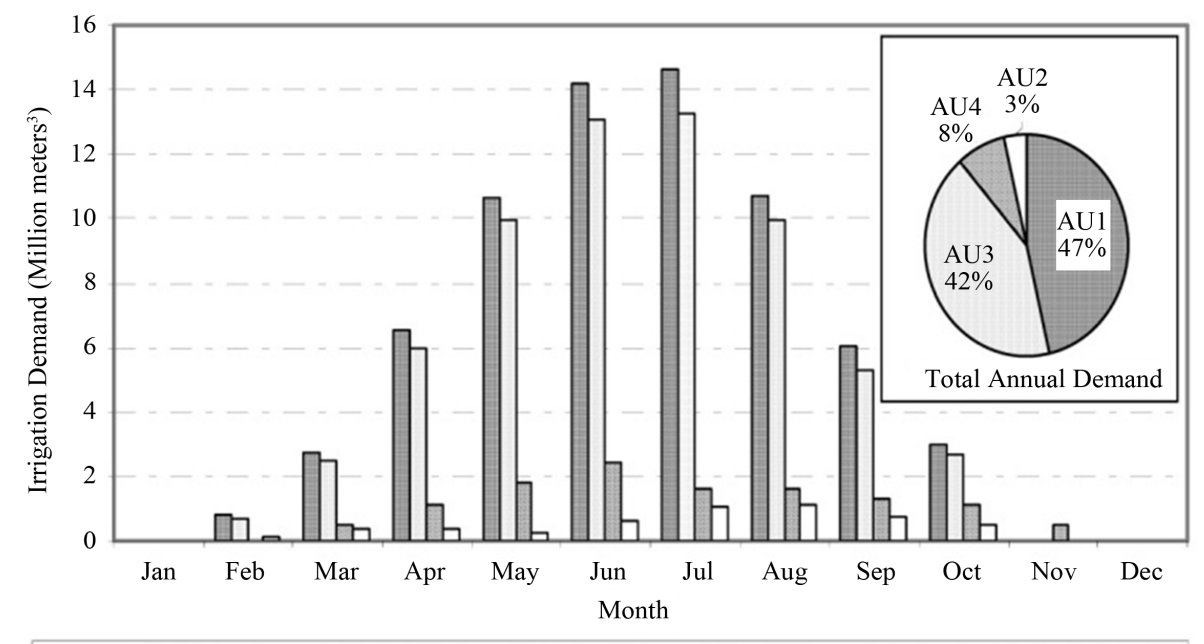

$\square$ AU1 (Right Bank) $\square$ AU3 (Left Bank) $\square$ AU4 (Uncontrolled Irrigation) $\square$ AU2 (Deurdeur Extension)

Figure 2. Monthly and total irrigation water demands.

Table 4. Operation levels for the three existing dams.

\begin{tabular}{cccc}
\hline & \multicolumn{3}{c}{ Volume $\left(\mathbf{1 0}^{\mathbf{6}} \mathbf{~ m}^{\mathbf{3}}\right)$} \\
\cline { 2 - 4 } & Ghrib & Deurdeur & Harreza $^{(*)}$ \\
\hline Maximal Volume & 200 & 165 & 90 \\
Spillway Level & 155 & 115 & 70 \\
Minimal Exploitation Level & 40 & 25 & 20 \\
Level at Start of Simulation & 155 & 25 & 20 \\
\hline
\end{tabular}

${ }^{(*)}$ The Harreza dam is currently in the filling phase and is therefore considered nonoperational. Consequently, the water volume at the start of the simulation is estimated as the dead storage volume $\left(20\right.$ million $\left.\mathrm{m}^{3}\right)$. As for the initial capacity for Deurdeur and Ghrib dams, they were chosen by the operating agency of the two dams.

\subsection{Conceptualization of Case A: Current Situation}

The conceptualization of the current system demands, supplies and control structures (base or current situation, case A) of Upper-Chéliff are shown in Figure 3(a) and Table 5. It comprises: 1) runoffs of gauged and nongauged basins, 2) the three existing dams of Ghrib, Deurdeur and Harreza, 3) urban and/or industrial water supply (provided by Ghrib and from Deurdeur); and 4) irrigation supply to units AU1, AU2, AU3 and the irrigated lands out of the sprinkler system network (AU4).

The water resources model was based on the following assumptions:

- The total demand of AU3 and AU4 are satisfied by Ghrib and Deurdeur dams without any particular priority;

- Harreza dam does not provide for irrigation in the Upper-Chéliff zone.

- El-Khémis II pumping station from November till March carries out the diversion of water surplus of Ghrib and Deurdeur Dams to Harreza. These months are matching the main rainy season in the region. Taking into account the total pumping head of El-Khémis II and the hydraulic system limitations, the rate of pumping was limited to $3 \mathrm{~m}^{3} / \mathrm{s}$.

- Given that the model covers only the Upper-Chéliff basin and that the three dams serve the demands downstream of AU3 and AU4 as well, a demand at the downstream end of the Upper-Chéliff was integrated in the model. This demand is regarded as the downstream supplement, which is released to the Middle-Chéliff. Table 6 gives monthly volumes of this supplement downstream [19]. 


\subsection{Conceptualization of Case B: Integration of the Projected Works}

The Harreza Dam can satisfy the water irrigation demands for left bank of the Upper-Chéliff (AU3) only by pumping, whereas it can provide the lands of the Middle-Chéliff without pumping. This is why two cases of operation were studied; the first with Harreza Dam providing for AU3 (denoted hereafter sub-alternative B1) to improve water allocation reliability of the Upper-Chéliff and the second sub-alternative without it (subalternative B2) to reduce Harreza pumping costs. It should be noted that when including Harreza in the UpperChéliff system, the confluence of Harreza and Chéliff Wadis is moved to Node 12.

Sub-alternative B1 is further divided into two, based on the operation rules as follows:

- Sub-alternative (B1-a) assumes that the left bank (AU3) irrigation demands is provided by the three (Ghrib,

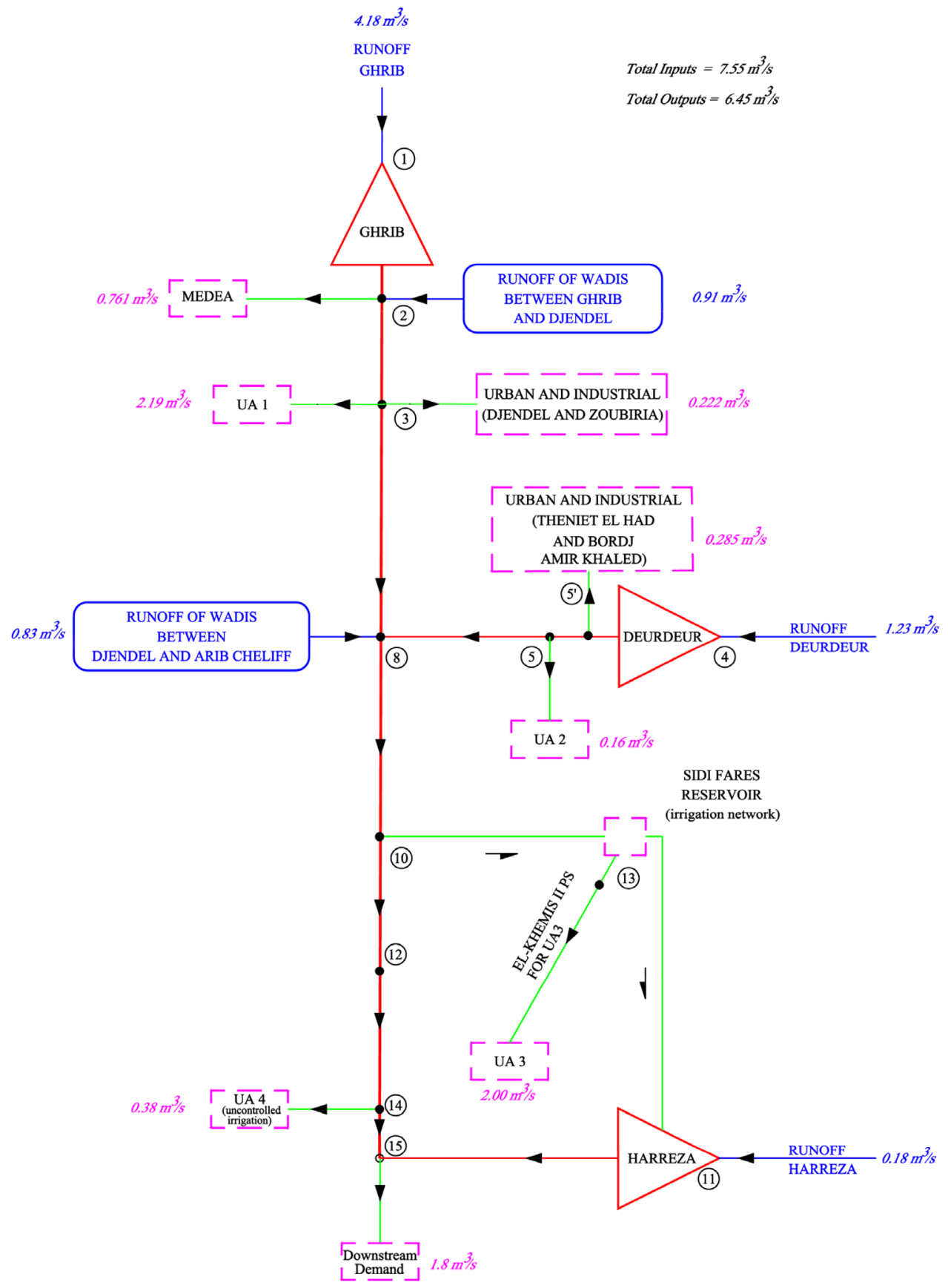

(a) 


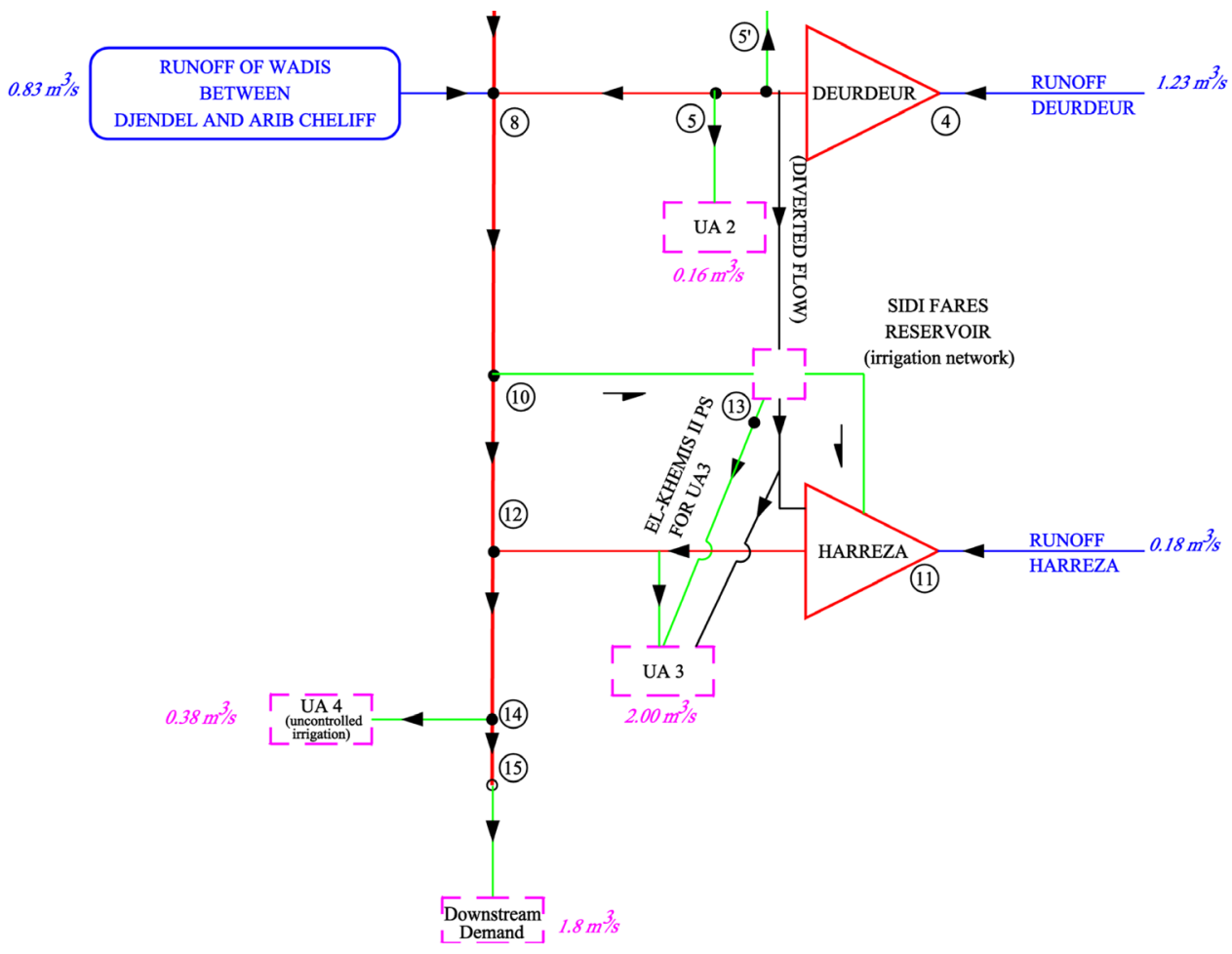

(b)

Figure 3. Conceptualization. (a) Conceptualization of current situation (Case A); (b) Changes in the conceptualization of sub-alternative B1-a.

\section{Table 5. Descriptive statistics for $\mathrm{Tr} / \mathrm{Ts}$ groups.}

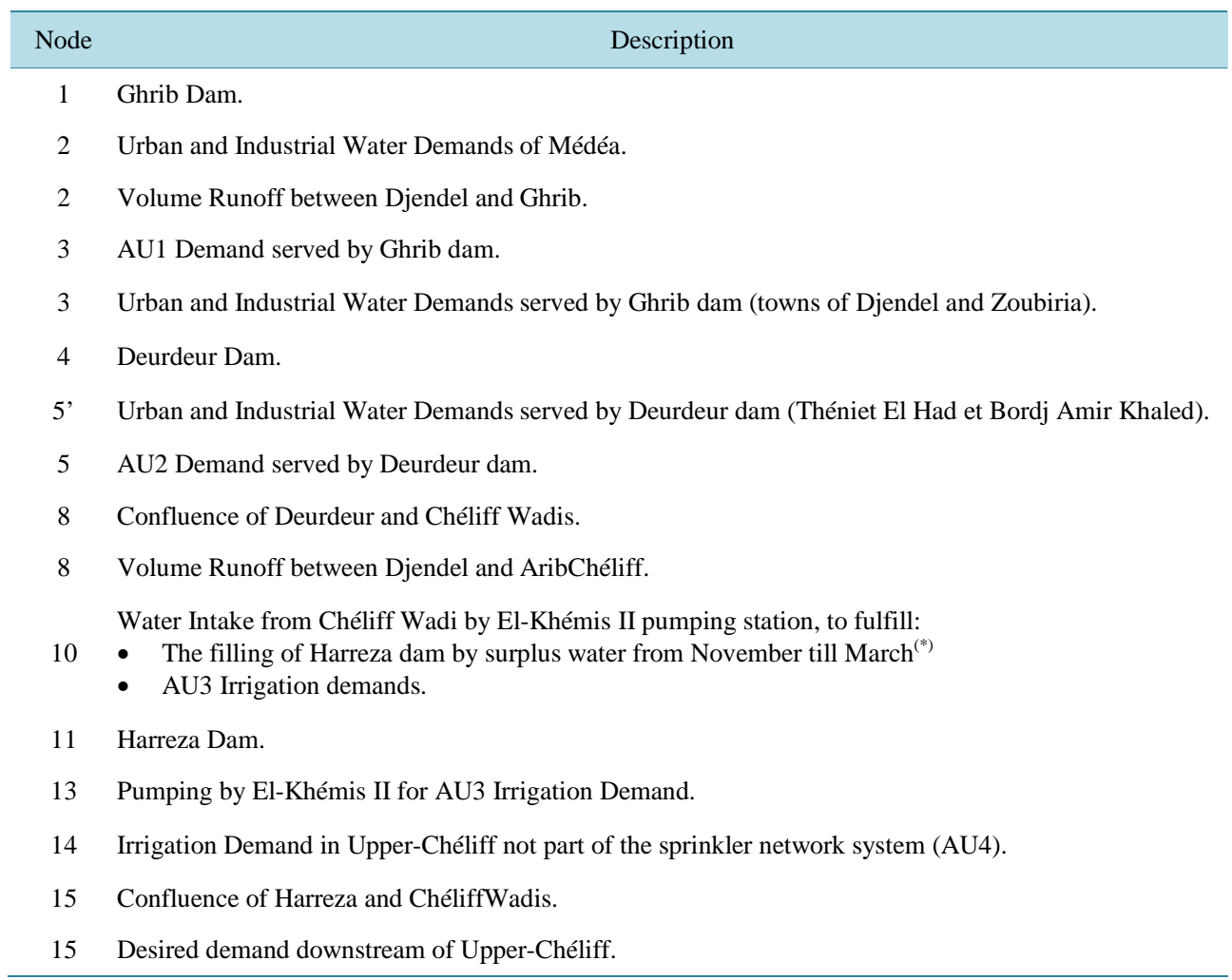


Table 6. Monthly release volumes downstream of Upper Chéliff.

\begin{tabular}{ccccccccccccc}
\hline Month & Sep & Oct & Nov & Dec & Jan & Feb & Mar & Apr & May & Jun & Jul & Aug \\
\hline Downstream releases $\left(10^{6} \mathrm{~m}^{3}\right)$ & 0.9 & 0.4 & 0 & 0 & 0 & 0 & 0 & 0 & 0 & 6.8 & 8.9 & 6.5 \\
\hline
\end{tabular}

Deurdeur and Harreza) dams without any particular priority. This sub-alternative is judicious to maximize the water allocation reliability without considering reducing the running pumping costs. Several values of the maximum capacity that the transfer pipe can accommodate were tested. This iterative study of the B1-a subalternative was carried out to determine the optimal capacity of this pipe. Figure 4 shows the cost of the pipeline as a function of the pipe capacity. The curve shows a breakpoint at $2.0 \mathrm{~m}^{3} / \mathrm{s}$ capacity. It is worth noting that the reliability of the system exhibits a breakpoint at the same capacity. The reliability of water allocation to AU3 is almost not affected beyond the $2.0 \mathrm{~m}^{3} / \mathrm{s}$ capacity.

- The second sub-alternative (B1-b) gives the priority to the Deurdeur Dam (through the gravity transfer) to satisfy the water demands for the AU3 and to minimize the pumping costs. Deurdeur dam is thus forced to provide for as much as possible of the AU3 demands. The Harreza Dam releases shall satisfy AU3 demands that are not satisfied by the Deurdeur gravity pipe. If AU3 is not completely provided by water from Deurdeur and Harreza, the pumping station of El-Khémis II should complement the difference by pumping from Ghrib releases present in the Chéliff Wadi.

Alternative (B2) is similar to sub-alternative B1-b in giving the priority to Deurdeur Dam to fulfill the water demands of AU3. Contrary to B1-b, the releases of Harreza Dam are intended to satisfy the demands downstream of Upper-Chéliff without pumping, thus in this perspective it is similar to the current situation, case A.

\section{Comparison Criteria among the Various Alternatives/Sub-Alternatives}

\subsection{Technical Criteria}

Several technical criteria are used for the evaluation of the various alternatives, namely the water allocation frequency of failure for the various demands, the shortage index as well as the monthly averages of the diverted flows from the Deurdeur Wadi.

The frequency of failure is calculated as the percentage of months when the demands are not fulfilled compared with the total number of months of simulation. The frequency of failure does not incorporate measurements of the severity of the water shortage. On the contrary, the shortage index does and it can be calculated as follows (Equation (1)):

$$
I D=\frac{100 \times \sum_{i=1}^{N}\left[\frac{S_{i A}}{D_{A}}\right]^{2}}{N}
$$

where:

$I D=$ shortage index;

$N=$ number of simulation years;

$S_{i A}=$ annual deficit of year $i$ (water demand-allocated volume);

$D_{A}=$ annual volume of the demand.

To compare the various alternatives, the monthly average of the regulated flows and specifically the diverted flows from the Deurdeur Wadi are calculated.

\subsection{Economic Criteria}

The electric power consumed is calculated for the pumping station of El-Khémis II and the pumping station of Harreza by using the following formula (Equation (2)):

$$
E=\frac{\gamma Q H}{75}
$$

where: 


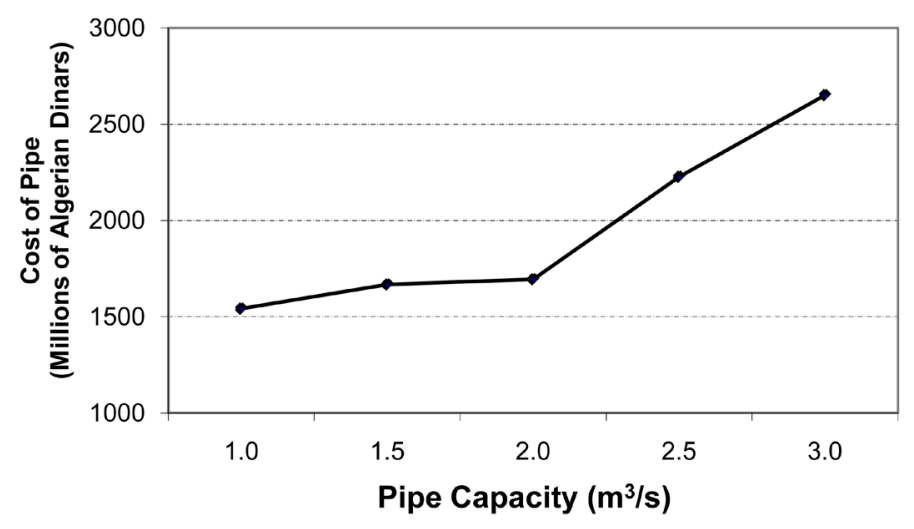

Figure 4. Cost of pipe for different values of pipe capacity.

$E=$ Power Consumption (HP);

$\gamma=$ Specific Weight of Water;

$Q=$ Discharge $\left(\mathrm{m}^{3} / \mathrm{s}\right)$;

$H=$ Total Head (m).

It should be noted that the total head for El-Khémis II pumping station is in the order of $110 \mathrm{~m}$, while the total head of Harreza pumping station vary between 45 and $65 \mathrm{~m}$ depending on the water level in the Harreza dam.

\section{Results and Evaluation}

The results of the different simulations, previously described, are summarized hereafter in Table 7 . Table 7 reveals that the reliability of sub-alternative B1-a is approximately 3\% lower than case A and sub-alternatives B1-b and B2. The average failure frequencies for all sub-alternatives, which is in the order of $5 \%$ for the municipal demand and of $15 \%$ for the irrigation demand in the Upper-Chéliff, are considered acceptable. It should be noted that the loss in reliability is due to increase in spillage from Ghrib. A sub-alternative, not presented in this paper, explored the possibility of giving the priority to Deurdeur Dam with constraints on no loss of reliability by controlling Ghrib spillage and forcing Ghrib to satisfy demands if storage is near top of conservation level. However, this sub-alternative resulted in a power consumption of 10,500 MWH/year, which-although lower than alternative B1-a-does not present a considerable economy in electrical consumption as achieved by subalternatives B1-b and B2. The choice between sub-alternatives B1-a B1-b and B2 will be based on the technoeconomic analysis presented in the next subsection.

Table 7 and Figure 5, show the average discharges of the diversion gravity pipe feeding the irrigation network. The difference from one alternative to the other is attributed to the differences of the operation rules. The releases of the Deurdeur Dam are affected by the change of the management policy. The B1-b and B2 sub-alternatives, which give a priority to Deurdeur to fulfill the needs for irrigation, tend to regulate the flows of the latter over all the year. The arithmetic average of these releases is slightly higher for the sub-alternatives B1-b and B2 than those for A and B1-a.

It should be noted that the diversion from Deurdeur do not increase the water allocation reliability, as the diversion system has no storage capacity. However, the projected works reduce considerably the costs of pumping from El-Khémis II station serving AU3. As shown in Table 7, the volumes pumped by El-Khémis II are reduced to half for the sub-alternatives B1-b and B2. The power reduction is also presented in Table 7.

\section{Techno-Economic Analysis}

The major parameters considered in the techno-economic analysis are the frequency of failure and the average shortage index coupled with the electrical power consumption.

In an attempt to properly select the most suitable alternative plan, the evaluation criteria previously discussed were subjected to further assessment. A matrix has been prepared comprising the above listed evaluation criteria (refer to Table 8). Each evaluation criterion has been given a priority weight representing its importance compared to each other; where the higher weight is given to the most influential one. 
Table 7. Results of the studied alternatives.

\begin{tabular}{|c|c|c|c|c|c|c|c|}
\hline \multirow{2}{*}{ Alternatives } & \multicolumn{2}{|c|}{ Failure Frequency (\%) } & \multicolumn{2}{|c|}{ Shortage Index (\%) } & \multirow{2}{*}{$\begin{array}{c}\text { Water diverted } \\
\text { from Deurdeur } \\
\left(\mathrm{m}^{3} / \mathrm{s}\right)\end{array}$} & \multirow{2}{*}{$\begin{array}{l}\text { Water pumped } \\
\text { from El-Khémis } \\
\text { II PS }\left(\mathbf{m}^{3} / \mathbf{s}\right)\end{array}$} & \multirow{2}{*}{$\begin{array}{l}\text { Electrical Energy } \\
\text { Consumption } \\
\text { (MWH/year) }\end{array}$} \\
\hline & Munic. & Irrig. & Munic. & Irrig. & & & \\
\hline A & 5.36 & 15.25 & 0.87 & 12.35 & - & 1.44 & 16,700 \\
\hline B1-a & 5.36 & 14.18 & 0.87 & 10.80 & 0.48 & 1.30 & 11,117 \\
\hline B1-b & 5.43 & 16.95 & 0.87 & 13.73 & 0.54 & 0.71 & 8646 \\
\hline B2 & 5.50 & 18.13 & 0.87 & 15.73 & 0.53 & 0.81 & 8951 \\
\hline
\end{tabular}

Table 8. Results of the techno-economic analysis.

\begin{tabular}{|c|c|c|c|c|c|c|c|c|c|c|c|c|c|}
\hline \multirow{3}{*}{$\begin{array}{c}\text { Evaluation } \\
\text { Criteria }\end{array}$} & \multirow{3}{*}{$\begin{array}{l}\text { Priority } \\
\text { Weight }\end{array}$} & \multicolumn{12}{|c|}{ Operation Rule Evaluation } \\
\hline & & \multicolumn{3}{|c|}{ Case A } & \multicolumn{3}{|c|}{ Alternative B1-a } & \multicolumn{3}{|c|}{ Alternative B1-b } & \multicolumn{3}{|c|}{ Alternative B2 } \\
\hline & & Value & $\begin{array}{l}\text { Impact } \\
\text { Weight }\end{array}$ & $\begin{array}{c}\text { Total } \\
\text { Weight }\end{array}$ & Value & $\begin{array}{l}\text { Impact } \\
\text { Weight }\end{array}$ & $\begin{array}{c}\text { Total } \\
\text { Weight }\end{array}$ & Value & $\begin{array}{l}\text { Impact } \\
\text { Weight }\end{array}$ & $\begin{array}{c}\text { Total } \\
\text { Weight }\end{array}$ & Value & $\begin{array}{l}\text { Impact } \\
\text { Weight }\end{array}$ & $\begin{array}{c}\text { Total } \\
\text { Weight }\end{array}$ \\
\hline $\begin{array}{l}\text { Frequency of } \\
\text { Failure }\end{array}$ & 2 & 11.0 & 0.95 & 1.90 & 10.4 & 1.00 & 2.00 & 12.0 & 0.87 & 1.74 & 12.7 & 0.82 & 1.64 \\
\hline Shortage Index & 2 & 6.80 & 0.87 & 1.74 & 5.90 & 1.00 & 2.00 & 7.90 & 0.75 & 1.50 & 9.10 & 0.65 & 1.30 \\
\hline $\begin{array}{c}\text { Energy } \\
\text { Consumption/Year }\end{array}$ & 5 & 16.7 & 0.52 & 2.60 & 11.1 & 0.78 & 3.90 & 8.65 & 1.00 & 5.00 & 8.95 & 0.97 & 4.85 \\
\hline \multicolumn{2}{|c|}{ Overall Grade } & 6.24 & 7.90 & 8.24 & 7.79 & 6.24 & 7.90 & 8.24 & 7.79 & 6.24 & 7.90 & 8.24 & 7.79 \\
\hline
\end{tabular}

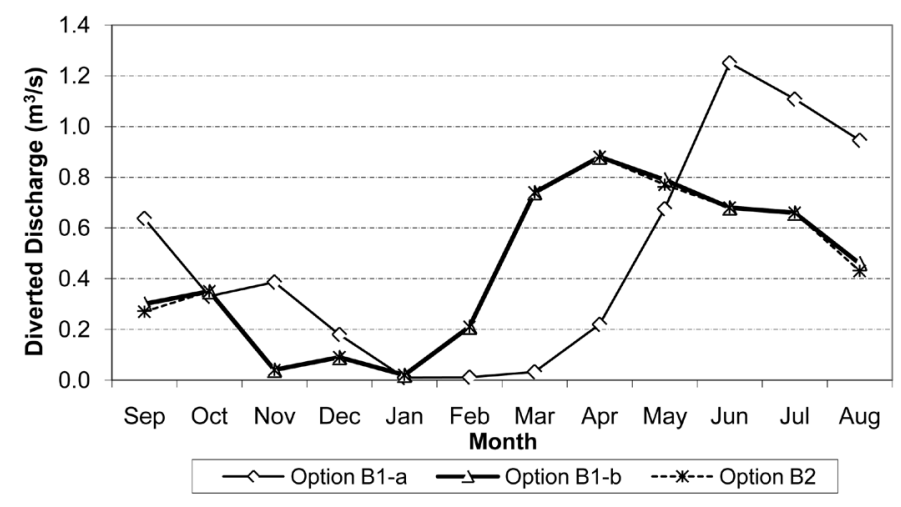

Figure 5. Average diverted discharges from the diversion weir for the different alternatives (the selected sub-alternative B1-b is shown in thicker lines).

In turn, each alternative would have an impact weight (less or equal to unity) on each evaluation criterion as induced from the aforesaid discussion. The largest impact (i.e. 1) would be given to the alternative considered to have the utmost satisfaction to this evaluation criterion. Thus the weight (1) is assigned to the frequency of failure criterion in Table 8 with the B1-a sub-alternative, which has the smallest value of frequency of failure (10.4). For this same criterion, the impact weight for another sub-alternative is calculated as the ratio of the best value for this criterion to its value for this sub-alternative. As such, the assigned weight of the frequency failure for sub-alternative B1-b is calculated as 10.4/12.0; that is to say 0.87. The multiplication of the priority weight and the impact weight for each cell results in the total weight. Finally, the summation of these total weights gives the total evaluation grade of which the higher value denotes the most suitable alternative plan.

Due to the fact that the frequency of failure for the satisfaction of various needs is lower than $25 \%$ with an average not exceeding $17 \%$, it has been judged that the technical and economic aspects have almost the same 
value of importance. Consequently, the following priority weights are used, after being accepted by the authorities managing the water allocation in Algeria:

- Frequency of failure = 2;

- Shortage Index = 2;

- Electrical power consumption $=5$.

The total overall grade is thus 9 (i.e. $2+2+5$ ). Table 8 shows the results of the techno-economic analysis. Sub-alternative B1-b is the most advantageous compared to the other alternatives with an overall grade of 8.24 out of 9.

A sensitivity analysis was carried on the priority weights. It showed that for a frequency failure of 2 and a shortage index of 2, Alternative B1-b remains the best alternative provided that the energy consumption priority weight remains bigger than 3.4, i.e. starting from an economic priority weight slightly lower than the sum of technical weights given to the frequency failure and the shortage index $(2+2=4)$. Furthermore, the evaluation result is not sensitive to the weight distribution between the technical criteria of failure as long as the economic criterion is at least as high as the sum of the technical criteria.

\section{Conclusions and Recommendations of the Techno-Economic Analysis}

The principal conclusions and recommendations adopted at the end of this study can be recapitulated as follows:

- The maximum transfer capacity from Deurdeur Wadi is determined as $2 \mathrm{~m}^{3} / \mathrm{s}$, thus assuring $40 \%$ of the irrigation demands of AU3 from the Deurdeur dam.

- Sub-alternatives B1-a and Case A are the best sub-alternatives from the standpoint of water demand satisfaction, as they ensure the best reliability for water allocation.

- From the economic standpoint, sub-alternative B1-b, which gives priority for AU3 water demand satisfaction from Deurdeur dam, is highly superior leading to a reduction of half the pumping costs with only $3 \%$ reduction in the water allocation reliability.

\section{Conclusions}

The allocation of water and the cost associated with it is a techno-economic decision. This decision is all the more difficult as the volume runoffs are irregular and rare and water demands are complex.

The case study presented in this paper aimed to determine the best water allocation policy taking into consideration allocation reliability, pumping costs, pipe capacities and reservoir operating rules. To achieve this goal, a water resources model was developed, using HEC-5 for the system of three dams, two pumping stations and a diversion structure, all serving several agricultural units.

A multi-criterion analysis was carried out based on the simulation results to determine the capacity of the diversion pipe, a new pumping station capacity and the policy of water allocation. The results of this analysis made it possible to set a policy of water distribution, to determine the capacity of projected diversion structure and to analyze the sensitivity of the system. The selected alternative based on the results permits a reduction of half the pumping costs with only $3 \%$ reduction in the water allocation reliability.

\section{References}

[1] Yeh, W. (1985) Reservoir Management and Operations Models: A State-of-the-Art-Review. Water Resources Research, 21, 1797-1818. http://dx.doi.org/10.1029/WR021i012p01797

[2] US Army Corps of Engineers, Hydrologic Engineering Center (1991) Optimization of Multiple-Purpose Reservoir System Operations: A Review of Modeling and Analysis Approaches. Research Document No. 34.

[3] Rani, D. and Moreira, M.M. (2010) Simulation-Optimization Modeling: A Survey and Potential Application in Reservoir. Water Resources Management, 24, 1107-1138. http://dx.doi.org/10.1007/s11269-009-9488-0

[4] Wurbs, R.A. (1993) Reservoir-System Simulation and Optimization Models. Journal of Water Resources Planning and Management, ASCE, 119, 455-472. http://dx.doi.org/10.1061/(ASCE)0733-9496(1993)119:4(455)

[5] Wurbs, R.A. (1994) Computer Models for Water Resources Planning and Management. Institute for Water Resources, Virginia, IWR Report 94-NDS-7.

[6] Wurbs, R.A. (1996) Modeling and Analysis of Reservoir System Operations. Prentice Hall, New Jersey.

[7] Labadie, J. (2004) Optimal Operation of Multireservoir Systems: State-of-the-Art Review. Journal of Water Resources 
Planning and Management, 130, 93-110. http://dx.doi.org/10.1061/(ASCE)0733-9496(2004)130:2(93)

[8] Robitaille, A., Welt, F. and Lafond, L. (1995) Development of a Real Time River Management System for HydroQuebec's Short Term Operation. Waterpower'95.

[9] Allen, R.B., Olason, T. and Bridgeman, S.G. (1996) A Decision Support System for Power Systems Operations Management. Proceedings of the ASCE Fifth Water Resources Operations Management Workshop, Arlington.

[10] Loucks, D.P., Salewicz, K.A. and Taylor, M.R. (1989) IRIS an Interactive River System Simulation Model, General Introduction and Description. Cornell University, Ithaca, International Institute for Applied Systems Analysis, Laxenburg.

[11] Wurbs, R.A. and Walls, W.B. (1989) Water Rights Modeling and Analysis. Journal of Water Resources Planning and Management, ASCE, 115, 416-430. http://dx.doi.org/10.1061/(ASCE)0733-9496(1989)115:4(416)

[12] Labadie, J. (1995) River Basin Model for Water Rights Planning, MODSIM: Technical Manual. Department of Civil Engineering, Colorado State University, Ft. Collins.

[13] Andreu, J., Capilla, J. and Sanchis, E. (1996) AQUATOOL, a Generalized Decision-Support System for Water-Resources Planning and Operational Management. Journal of Hydrology, 177, 269-291. http://dx.doi.org/10.1016/0022-1694(95)02963-X

[14] WEAP (1997) Water Evaluation and Planning System Users Guide. Tellus Institute, Boston.

[15] US Army Corps of Engineers, Hydrologic Engineering Center (1998) HEC-5 Simulation of Flood Control and Conservation Systems User's Manual. Version 8.0, Davis.

[16] Eschenbach, E.A., Magee, T., Zagona, E., Goranflo, M. and Shane, R. (2001) Goal Programming Decision Support System for Multiobjective Operation of Reservoir Systems. Journal of Water Resources Planning and Management, 127, 108-120. http://dx.doi.org/10.1061/(ASCE)0733-9496(2001)127:2(108)

[17] Fayaed, S.S., Ahmed El-Shafie, A. and Jaafar, O. (2012) Reservoir-System Simulation and Optimization Techniques. Stochastic Environmental Research and Risk Assessment, 27, 1751-1772. http://dx.doi.org/10.1007/s00477-013-0711-4

[18] PNE (1997) Plan National de l’Eau. Groupement Beture, Carl Bro et CES Salzgitter.

[19] (1984) SOGREAH Étude du Schéma directeur des ressources en eau du Chéliff et réaménagement du périmètre du Bas Chéliff. Rapport B2, SOGREAH Ingénieurs Conseil et SNC Montréal. 
Scientific Research Publishing (SCIRP) is one of the largest Open Access journal publishers. It is currently publishing more than 200 open access, online, peer-reviewed journals covering a wide range of academic disciplines. SCIRP serves the worldwide academic communities and contributes to the progress and application of science with its publication.

Other selected journals from SCIRP are listed as below. Submit your manuscript to us via either submit@scirp.org or Online Submission Portal.
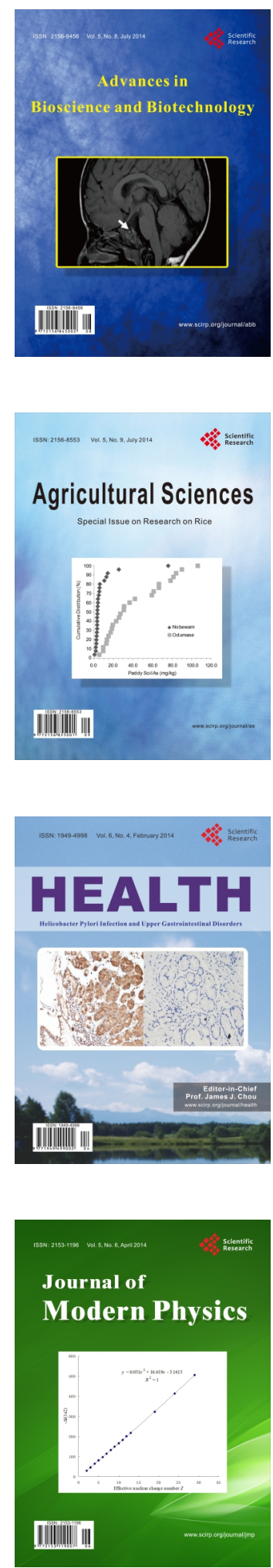
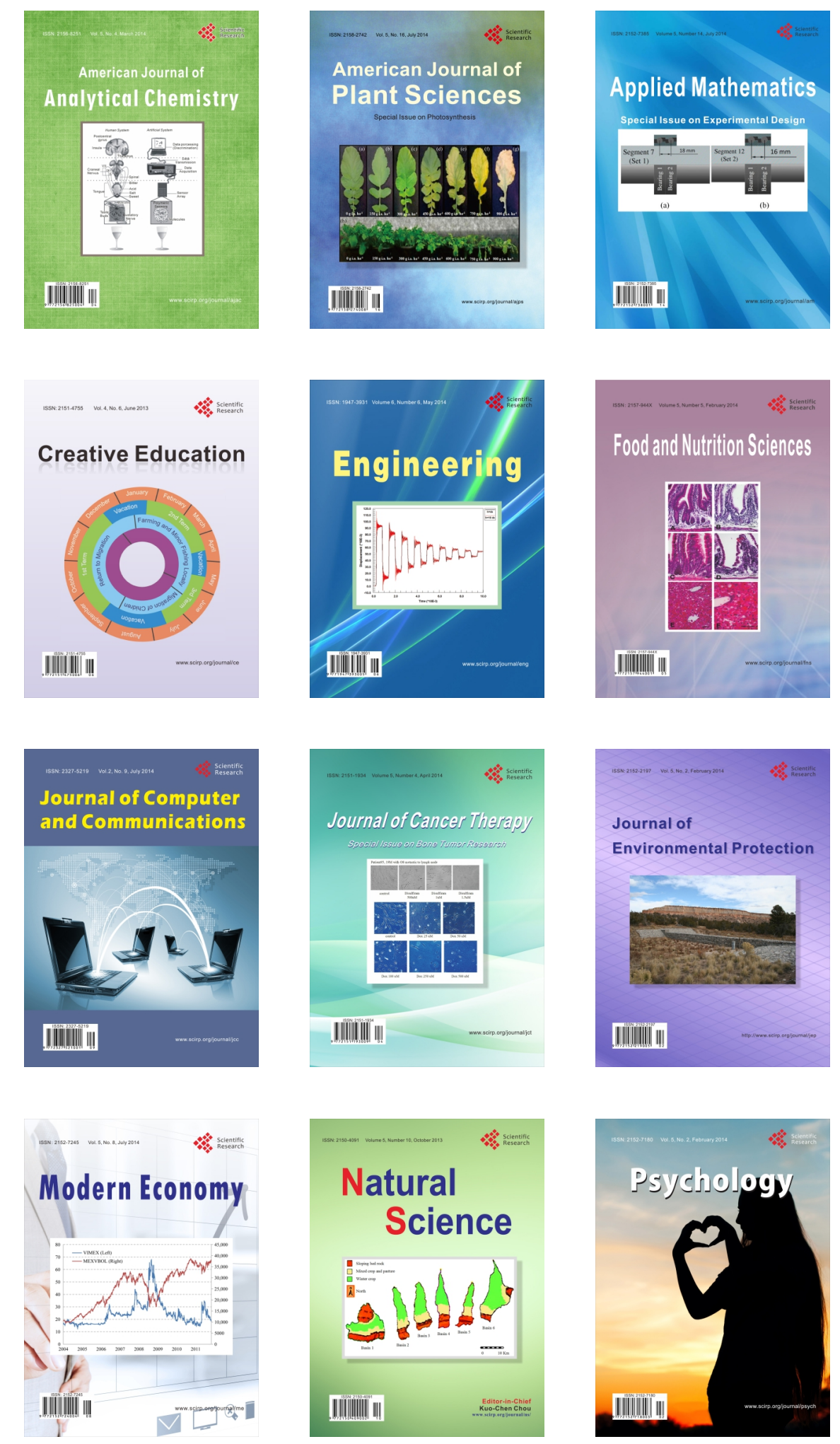